\title{
Ecology of Mosquitoes (Diptera: Culicidae) in Areas of Serra do Mar State Park, State of São Paulo, Brazil. III - Daily Biting Rhythms and Lunar Cycle Influence
}

\author{
Anthony Érico Guimarães ${ }^{+}$, Carla Gentile, Catarina Macedo Lopes, \\ Rubens Pinto de Mello
}

\author{
Laboratório de Diptera, Departamento de Entomologia, Instituto Oswaldo Cruz, Av. Brasil 4365, 21045-900 \\ Rio de Janeiro, RJ, Brasil
}

The ecology of mosquito species (Diptera: Culicidae) was studied in areas of the Serra do Mar State Park, State of São Paulo, Brazil. The influence of the lunar cycle and the daily biting rhythms of mosquito populations were analyzed. Systematized biweekly human bait collections were made in a silvatic environment for 24 consecutive months (January 1991 to December 1992). A total of 20,591 specimens of adult mosquitoes belonging to 55 species were collected from 545 catches.

Sabethini species were captured exclusively during daylight periods, with the exception of Trichoprosopon digitatum, while members of Anophelinae predominated during nocturnal hours. Members of the subfamily Culicinae that were collected primary during nocturnal periods included Culex nigripalpus, Coquillettidia chrysonotum and $\mathrm{Cq}$. venezuelensis while daytime catches included Psorophora ferox and Ps. albipes. Others members of culicines mosquitoes that were collected during both day and night included: Aedes serratus, Ae. scapularis and Ae. fulvus.

Lunar cycles did not appear to influence the daily biting rhythms of most mosquito species in the area, but larger numbers of mosquitoes were collected during the new moon. Ae. scapularis were captured mainly during the full moon.

Key words: mosquitoes - ecology - vectors - Atlantic Forest - Brazil

The daily biting rhythms and the possible effects of lunar cycles on mosquito population behavior are described as part of the ongoing study of the mosquito ecology in areas of the Serra do Mar State Park (PESM), Picinguaba Nucleus, city of Ubatuba, State of São Paulo. The monthly frequency, climatic factors and habitat distribution of mosquitoes have been previously described (Guimarães et al. 2000a,b).

\section{MATERIALS AND METHODS}

Three collections sites (A/B/C), described previously (Guimarães et al. 2000a,b), were selected in sylvatic environments in PESM. Biweekly collections were made during different periods of the day using human bait from January 1991 to December 1992.

\footnotetext{
This work is part of the main author's $\mathrm{PhD}$ thesis and was accomplished with the help of $\mathrm{CNPq}$, process no. 41.1613/88.

${ }^{+}$Corresponding author. Fax: +55-21-290.9339. E-mail: anthony@fiocruz.br

Received 27 October 1999

Accepted 3 July 2000
}

Biweekly collections in sites A, B and C were conducted during three periods each day: daylight (10-12 $\mathrm{h}$ and 14-16 h) and nocturnal (18-21 h). For each sampling period, two team members were collected landing/biting mosquitoes by mouth aspirators and placed in screen topped boxes.

Collected mosquitoes were killed with chloroform and placed in labeled boxes. Mosquitoes were returned to the laboratory where they were identified according to current literature and systematic proposals of Harbach and Kitching (1998) and Judd $(1996,1998)$ for the Sabethini tribe. Representative specimens were incorporated in the Entomological Collection, Department of Entomology, Oswaldo Cruz Institute, Fiocruz, under the title of "Atlantic Forest Collection".

Mosquito species daily biting rhythms and influence of lunar cycle were determined by using Williams averages $\left(\mathrm{X}_{\mathrm{w}}\right)$ according to the definitions of Haddow $(1954,1960)$ and Forattini et al. (1981). To analyze the significance of the influence of the lunar cycle upon the mosquitoes population the Kruskal-Wallis test (Kruskal \& Wallis 1952) was applied. In this test, the variables analyzed are considered as influential for the species occurrences when the $H$ value found is higher than the $H$ critical value. Numbers lower than $H$ critical 
value indicate that the referred variables are not influencing the species and any differences observed in its incidence are not directly related to those aspects. For the present case and with a significance level $\alpha=0.05$ we have the critical value $\mathrm{H}_{0.05,4,4,4,4}=7.24$.

Only species with a nocturnal biting cycle were analyzed with respect to the lunar cycle. Graphic representations and statistical analyses were made only for species that represented a total number of collected individuals $>1 \%$ of the members of each sub-family or tribe collected.

\section{RESULTS}

Daily biting rhythms - The hematophagic cycles of the mosquitoes sampled in most cases were clearly linked to either the diurnal or nocturnal periods of the day. Generally, members of the subfamily Anophelinae were active during nocturnal hours while members of the tribe Sabethini were active during daytime hours. Members of other Culicinae tribes were primarily active during the day or night, depending upon the species (Table, Fig. 1). The importance of the day or night periods in the mosquitoes activity becomes very clear through the Williams average displayed in the graphics at Fig. 1, indicating the great and direct response of all analyzed species to the day/night periods. The more common species for each of those three groups are analyzed below.

Anopheles fluminensis was the most common anopheline species in nocturnal samples, with $98 \%$ of the specimens collected during this period of the day and $X_{w}=4.0$. The other anopheline species captured during the night were $A n$. mediopunctatus s. $l$. $\left(94 \%, \mathrm{X}_{\mathrm{w}}=16.9\right), A n$. oswaldoi $\left(88 \%, \mathrm{X}_{\mathrm{w}}=2.7\right)$ and An. cruzii $(88 \%$, $\left.\mathrm{X}_{\mathrm{w}}=10.3\right)($ Table $)$.
Among non-Sabethini Culicinae, Culex nigripalpus showed a clear preference for the nocturnal period $\left(96 \%, \mathrm{X}_{\mathrm{w}}=13.8\right)$ (Table). Aedes scapularis and Ae. serratus were collected during all collections. Ae. fulvus was the most frequently collected Aedes species, and although collected during the day it was more frequently collected during the nocturnal period $\left(75 \%, \mathrm{X}_{\mathrm{w}}=7.3\right)$ (Fig. 1). Members of Culicinae that were collected primarily during nocturnal periods (except for $C x$. nigripalpus) included Coquillettidia chrysonotum and then $C q$. venezuelensis. Psorophora ferox and Ps. albipes were the only other members of Culicinae that were active during daytime; 93\%, $\mathrm{X}_{\mathrm{w}}=74.8$ and $88 \%, \mathrm{X}_{\mathrm{w}}=39.6$ respectively (Table, Fig. 1).

The Sabethini is a group of mosquitoes with typical sylvatic behavior and diurnal hematophagic activity. Trichoprosopon pallidiventer were collected almost exclusively during the diurnal periods $\left(99.3 \%, \mathrm{X}_{\mathrm{w}}=3.5\right)$. The only exception was $\mathrm{Tr}$. digitatum that were collected mainly during nocturnal periods (Fig. 1). Runchomyia reversa and $R u$. frontosa showed a clear preference for biting in daylight $\left(90.6 \%, \mathrm{X}_{\mathrm{w}}=4.3 ; 90.5 \%, \mathrm{X}_{\mathrm{w}}=10.7\right)$ (Table, Fig. 1). Wyeomyia species followed a similar pattern in preferring the diurnal period. $W y$. shannoni occurred exclusively in these samples (Fig. 1). Wy. (Phoniomyia) was the group of Sabethini species that most clearly showed a tendency for diurnal biting. Among the studied species, three occurred exclusively in these samples: $W y$. palmata, Wy. longirostris and Wy. davisi $\left(100 \%, \mathrm{X}_{\mathrm{w}}=2.4 ; 100 \%, \mathrm{X}_{\mathrm{w}}=20.2 ; 100 \%, \mathrm{X}_{\mathrm{w}}=\right.$ 3.7) (Fig. 1). More than $97 \%$ of specimens of the other species of Wyeomyia were collected during diurnal periods (Table). Limatus flavisetosus, Li. durhami and Li. pseudomethisticus were also cap-

\section{TABLE}

Number $(\mathrm{N})$, percentage $(\%)$ and Willians averages $\left(\mathrm{X}_{\mathrm{w}}\right)$ of Culicidae, according do the species distribution for the day and night periods, at the Picinguaba Nucleus of Serra do Mar State Park, State of São Paulo, January 1991 to December 1992

\begin{tabular}{|c|c|c|c|c|c|c|c|c|}
\hline \multirow[t]{2}{*}{ Species } & \multicolumn{3}{|c|}{ Day } & \multicolumn{3}{|c|}{ Night } & \multicolumn{2}{|c|}{ Total } \\
\hline & $\mathrm{N}$ & $\%$ & $\mathrm{X}_{\mathrm{W}}$ & $\mathrm{N}$ & $\%$ & $\mathrm{X}_{\mathrm{W}}$ & $\mathrm{N}$ & $\%$ \\
\hline \multicolumn{9}{|c|}{ A N OP HEL I N A E } \\
\hline Anopheles cruzii & 35 & 12.5 & 2.49 & 246 & 87.5 & 10.29 & 281 & 32.8 \\
\hline Anopheles argyritarsis & 0 & 0.0 & 0.00 & 2 & 100.0 & 0.10 & 2 & 0.2 \\
\hline Anopheles oswaldoi & 7 & 12.3 & 0.36 & 50 & 87.7 & 2.74 & 57 & 6.7 \\
\hline Anopheles strodei & 0 & 0.0 & 0.00 & 1 & 100.0 & 0.06 & 1 & 0.1 \\
\hline Anopheles intermedius & 0 & 0.0 & 0.00 & 6 & 100.0 & 0.30 & 6 & 0.7 \\
\hline Anopheles fluminensis & 3 & 2.0 & 0.19 & 147 & 98.0 & 3.99 & 150 & 17.5 \\
\hline Anopheles mediopunctatus & 20 & 5.6 & 1.02 & 339 & 94.4 & 16.91 & 359 & 41.9 \\
\hline Sub-total & 65 & 7.6 & 4.82 & 791 & 92.4 & 50.60 & 856 & 100.0 \\
\hline
\end{tabular}


cont.

\begin{tabular}{|c|c|c|c|c|c|c|c|c|}
\hline \multirow[t]{2}{*}{ Species } & \multicolumn{3}{|c|}{ Day } & \multicolumn{3}{|c|}{ Night } & \multicolumn{2}{|c|}{ Total } \\
\hline & $\mathrm{N}$ & $\%$ & $\mathrm{X}_{\mathrm{W}}$ & $\mathrm{N}$ & $\%$ & $\mathrm{X}_{\mathrm{W}}$ & $\mathrm{N}$ & $\%$ \\
\hline \multicolumn{9}{|c|}{ C U L I C I n A E (except SABETHINI) } \\
\hline Culex nigripalpus & 11 & 3.8 & 0.68 & 275 & 96.2 & 13.75 & 286 & 2.0 \\
\hline Orthopodomyia albicosta & 0 & 0.0 & 0.00 & 1 & 100.0 & 0.06 & 1 & 0.0 \\
\hline Aedes serratus & 726 & 45.4 & 52.10 & 872 & 54.6 & 66.23 & 1598 & 11.2 \\
\hline Aedes scapularis & 178 & 42.6 & 12.37 & 240 & 57.4 & 16.30 & 418 & 2.9 \\
\hline Aedes fluviatilis & 15 & 100.0 & 0.33 & 0 & 0.0 & 0.00 & 15 & 0.1 \\
\hline Aedes fulvus & 65 & 25.6 & 3.32 & 189 & 74.4 & 7.33 & 254 & 1.8 \\
\hline Aedes terrens & 8 & 72.7 & 0.46 & 3 & 27.3 & 0.12 & 11 & 0.1 \\
\hline Coquillettidia chrysonotum & 635 & 7.4 & 26.85 & 7907 & 92.6 & 253.18 & 8542 & 59.7 \\
\hline Coquillettidia venezuelensis & 95 & 8.6 & 6.07 & 1016 & 91.4 & 54.03 & 1111 & 7.8 \\
\hline Psorophora ferox & 1197 & 93.1 & 74.77 & 89 & 6.9 & 4.81 & 1286 & 9.0 \\
\hline Psorophora albipes & 668 & 88.0 & 39.60 & 91 & 12.0 & 3.05 & 759 & 5.3 \\
\hline Haemagogus leucocelaenus & 16 & 100.0 & 1.08 & 0 & 0.0 & 0.00 & 16 & 0.1 \\
\hline Haemagogus capricornii & 3 & 100.0 & 0.16 & 0 & 0.0 & 0.00 & 3 & 0.0 \\
\hline Uranotaenia geometrica & 1 & 50.0 & 0.06 & 1 & 50.0 & 0.06 & 2 & 0.0 \\
\hline$\overline{\text { Sub-total }}$ & 3618 & 25.3 & 262.91 & 10684 & 74.7 & 553.30 & 14302 & 100.0 \\
\hline \multicolumn{9}{|c|}{ S ABETHINI } \\
\hline Shannoniana fluviatilis & 1 & 100.0 & 0.06 & 0 & 0.0 & 0.00 & 1 & 0.0 \\
\hline Trichoprosopon digitatum & 20 & 26.7 & 1.24 & 55 & 73.3 & 2.56 & 75 & 1.4 \\
\hline Trichoprosopon pallidiventer & 150 & 99.3 & 3.51 & 1 & 0.7 & 0.06 & 151 & 2.8 \\
\hline Trichoprosopon simile & 6 & 100.0 & 0.38 & 0 & 0.0 & 0.00 & 6 & 0.1 \\
\hline Runchomyia lunata & 4 & 57.1 & 0.26 & 3 & 42.9 & 0.16 & 7 & 0.1 \\
\hline Runchomyia reversa & 77 & 90.6 & 4.34 & 8 & 9.4 & 0.51 & 85 & 1.6 \\
\hline Runchomyia theobaldi & 36 & 94.7 & 0.96 & 2 & 5.3 & 0.10 & 38 & 0.7 \\
\hline Runchomyia frontosa & 162 & 90.5 & 10.68 & 17 & 9.5 & 0.64 & 179 & 3.3 \\
\hline Runchomyia humboldti & 6 & 100.0 & 0.25 & 0 & 0.0 & 0.00 & 6 & 0.1 \\
\hline Wyeomyia dyari & 511 & 92.9 & 31.60 & 39 & 7.1 & 1.42 & 550 & 10.1 \\
\hline Wyeomyia confusa & 122 & 91.0 & 6.78 & 12 & 9.0 & 0.55 & 134 & 2.5 \\
\hline Wyeomyia mystes & 531 & 96.2 & 36.61 & 21 & 3.8 & 0.94 & 552 & 10.2 \\
\hline Wyeomyia aporonoma & 554 & 99.3 & 39.24 & 4 & 0.7 & 0.23 & 558 & 10.3 \\
\hline Wyeomyia personata & 12 & 100.0 & 0.54 & 0 & 0.0 & 0.00 & 12 & 0.2 \\
\hline Wyeomyia shannoni & 109 & 100.0 & 5.81 & 0 & 0.0 & 0.00 & 109 & 2.0 \\
\hline Wyeomyia oblita & 1 & 100.0 & 0.06 & 0 & 0.0 & 0.00 & 1 & 0.0 \\
\hline Wyeomyia theobaldi & 244 & 99.2 & 7.10 & 2 & 0.8 & 0.12 & 246 & 4.5 \\
\hline Wyeomyia flabelata & 390 & 99.0 & 28.96 & 4 & 1.0 & 0.19 & 394 & 7.3 \\
\hline Wyeomyia pilicauda & 11 & 100.0 & 0.63 & 0 & 0.0 & 0.00 & 11 & 0.2 \\
\hline Wyeomyia splendida & 339 & 97.7 & 19.56 & 8 & 2.3 & 0.32 & 347 & 6.4 \\
\hline Wyeomyia palmata & 63 & 100.0 & 2.38 & 0 & 0.0 & 0.00 & 63 & 1.2 \\
\hline Wyeomyia longirostris & 325 & 100.0 & 20.21 & 0 & 0.0 & 0.00 & 325 & 6.0 \\
\hline Wyeomyia quasilongirostris & 169 & 97.7 & 10.49 & 4 & 2.3 & 0.20 & 173 & 3.2 \\
\hline Wyeomyia davisi & 71 & 100.0 & 3.66 & 0 & 0.0 & 0.00 & 71 & 1.3 \\
\hline Wyeomyia bonnei & 328 & 97.9 & 19.72 & 7 & 2.1 & 0.33 & 335 & 6.2 \\
\hline Wyeomyia lassalli & 55 & 98.2 & 0.56 & 1 & 1.8 & 0.06 & 56 & 1.0 \\
\hline Limatus flavisetosus & 497 & 99.6 & 29.77 & 2 & 0.4 & 0.12 & 499 & 9.2 \\
\hline Limatus durhami & 129 & 99.2 & 8.01 & 1 & 0.8 & 0.06 & 130 & 2.4 \\
\hline Limatus pseudomethisticus & 287 & 99.0 & 18.47 & 3 & 1.0 & 0.19 & 290 & 5.3 \\
\hline Sabethes quasicyaneus & 3 & 100.0 & 0.19 & 0 & 0.0 & 0.00 & 3 & 0.1 \\
\hline Sabethes intermedius & 1 & 100.0 & 0.06 & 0 & 0.0 & 0.00 & 1 & 0.0 \\
\hline Sabethes identicus & 19 & 100.0 & 0.58 & 0 & 0.0 & 0.00 & 19 & 0.4 \\
\hline Sabethes fabricii & 3 & 100.0 & 0.19 & 0 & 0.0 & 0.00 & 3 & 0.1 \\
\hline Sabethes soperi & 3 & 100.0 & 0.19 & 0 & 0.0 & 0.00 & 3 & 0.1 \\
\hline Sub-total & 5239 & 96.4 & 379.08 & 194 & 3.6 & 7.57 & 5433 & 100.0 \\
\hline Total & 8922 & 43.3 & 721.00 & 11669 & 56.7 & 638.42 & 20591 & 100.0 \\
\hline
\end{tabular}


tured with preferences for the daylight periods $\left(99.6 \%, X_{\mathrm{w}}=29.8 ; 99.2 \%, \mathrm{X}_{\mathrm{w}}=8.0 ; 99 \%, \mathrm{X}_{\mathrm{w}}=\right.$ 18.5) (Fig. 1).

Lunar cycle - According to the Kruskal-Wallis test it was observed that the lunar cycle exercises no direct influence on the culicidae fauna (Fig. 2), and so its population incidence does not vary significantly according to the phases of the moon. Even though, observations of the nature behavior and graphics of the Williams average of each species (Fig. 2) indicate a slight variation of some of these species at one or other lunar phase.
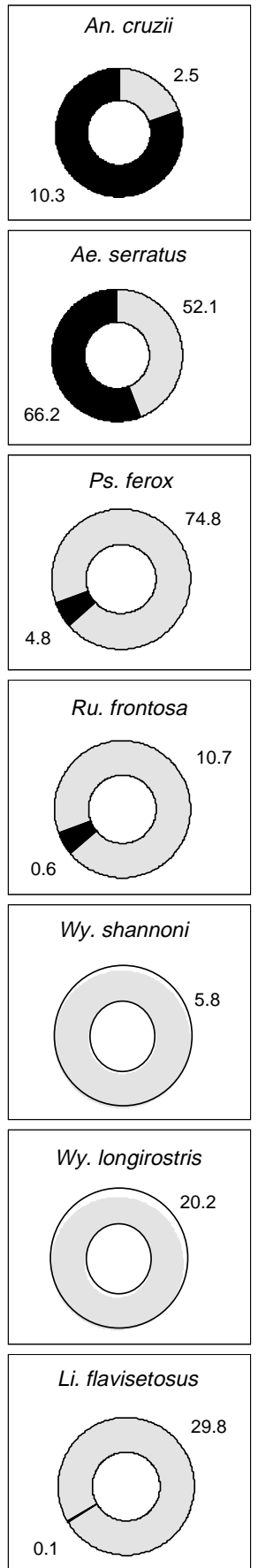
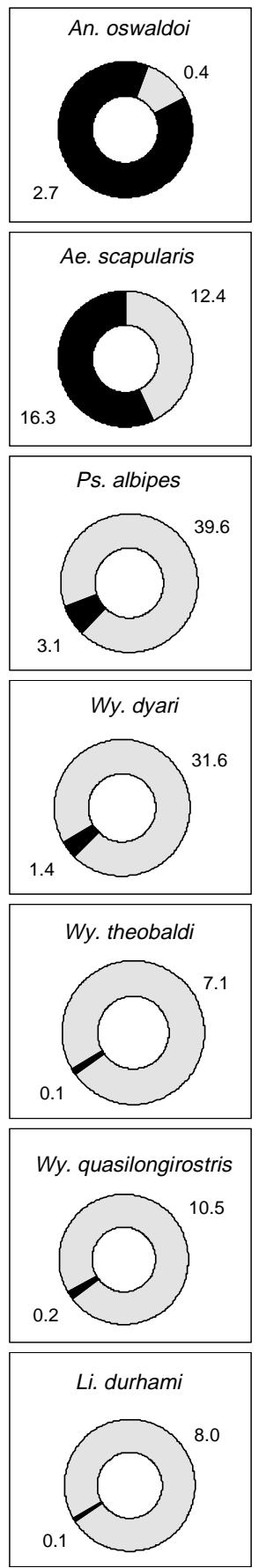
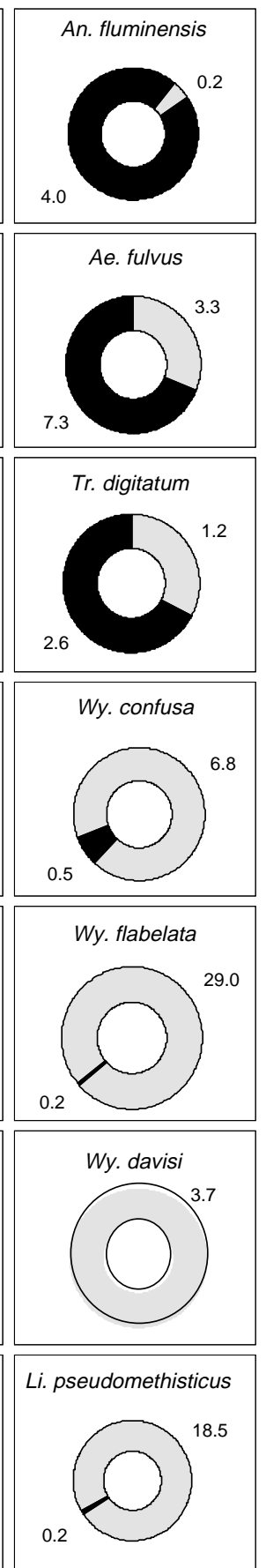
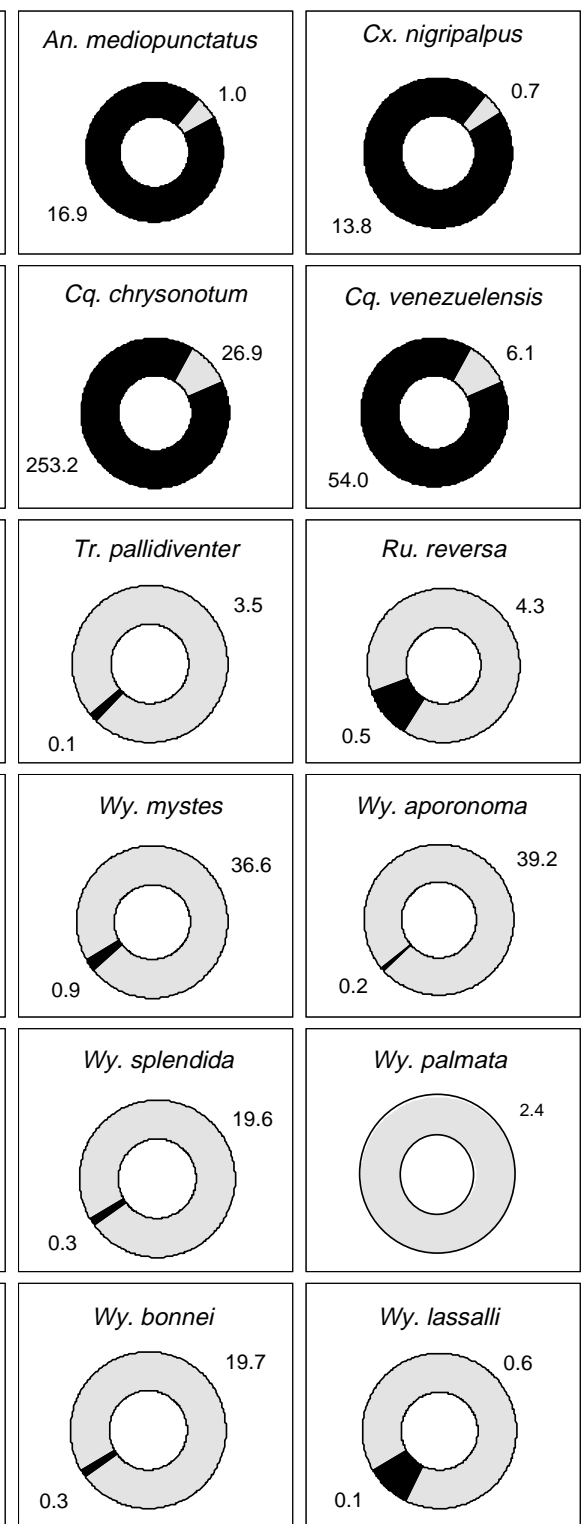

\section{Diurnal}

Nocturnal

Fig. 1: diurnal and nocturnal Culicidae species frequency, according to calculation of Williams averages $\left(\mathrm{X}_{\mathrm{w}}\right)$, Picinguaba Nucleus of Serra do Mar State Park, State of São Paulo, January 1991 to December 1992 

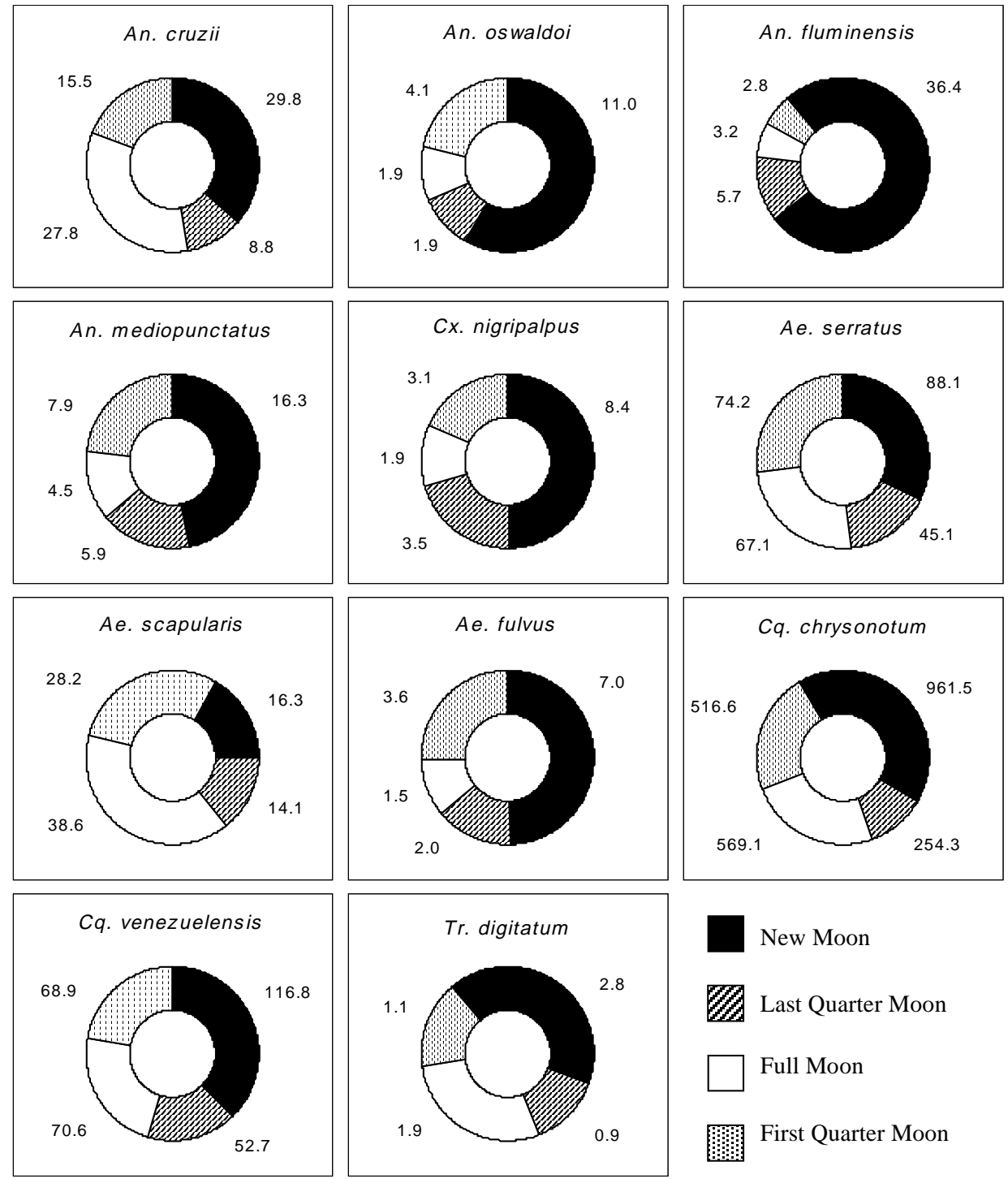

Fig. 2: the effect of the lunar cycle on Culicidae species, according to calculation of Williams averages $\left(\mathrm{X}_{\mathrm{w}}\right)$, Picinguaba Nucleus of Serra do Mar State Park, State of São Paulo, January 1991 to December 1992. At the bottom right corner of each graphic there is the $H$ value, that is the result of the Kruskal-Wallis test of significance, and the $H$ critical value is $H_{0.05,4,4,4,4}=$ 7.24 .

Among Culicidae species with nocturnal activity patterns, only Ae. scapularis did not demonstrated a preference for biting during the nights of the new moon (Fig. 2).

The species of Anophelinae that showed the greatest preference for the darkest nights was $A n$. fluminensis $(\mathrm{H}=4.80)$. An. oswaldoi and $A n$. mediopunctatus captures did not change throughout the lunar cycles. An. cruzii was more frequently collected during the new moon but was also captured in significant numbers during the first and last quarter moons (Fig. 2).

CX. nigripalpus were collected more frequently during the new moon $\left(\mathrm{X}_{\mathrm{w}}=8.4\right)$, followed by the last and first quarter moons $\left(X_{w}=3.5 ; X_{w}=3.1\right)$. This species was poorly found during the full moon $\left(\mathrm{X}_{\mathrm{w}}=1.9\right)$ (Fig. 2).

Ae. fulvus was also more abundant at nights of the new moon $(H=1.61)$, which Ae. serratus also preferred but not so intensely $(\mathrm{H}=0.75)$. Ae. scapularis was the only species of Aedes that was collected more frequently during the full moon $(\mathrm{H}$ = 3.72) (Fig. 2).

Cq. chrysonotum and Cq. venezuelensis presented similar distributions throughout the lunar cycles. However, during the new moon $C q$. 
chrysonotum showed a slightly higher preponderance than Cq. venezuelensis $(\mathrm{H}=3.82 ; \mathrm{H}=2.36)$ (Fig. 2).

Tr. digitatum was the only Sabethini species that occurred mainly in nocturnal samples. This behavior to bite during the darker periods is clearly demonstrated in the lunar cycle data $(\mathrm{H}=1.06)$ (Fig. 2).

\section{DISCUSSION}

Daily biting rhythms - The study of the hematophagic activity of mosquito species facilitates a better understanding of transmission of human and/or animal pathogens. For this purpose, there are two main issues to be considered: mosquito biting rhythms and the host on which the mosquito feeds.

Bates (1949) observed that the age and type of vegetation coverage could determine the incidence of hematophagous insects. An older forest with vegetation 15 to $20 \mathrm{~m}$ in height, similar to that found at Pinciguaba Nucleus in PESM tends to favor birds and arboreal mammals. Birds are active during the day and so are related to nocturnal acrodendrophilic mosquitoes and in some cases almost exclusively to ornithophilic species. Arboreal mammals are active during different periods of the day. Monkeys are diurnal animals and so favor the hematophagic activity of nocturnal acrodendrophilic mosquitoes. Deane et al. $(1969,1971)$ discuss about the importance of this behavior in the transmission of simian malaria. On the other hand, those monkeys are also frequently bitten by Sabethini, which are mosquitoes with a diurnal acrodendrophilic behavior and related to the cycle of jungle yellow fever (Galindo et al. 1966). Small rodents and marsupials are, by their turns, active during the night period and so serve as better hosts for diurnal mosquitoes, in all parts of the forest.

Machado-Allison (1982) observed that many Culicidae species have their activity period related to the resting time of the hosts on which they feed. Veloso et al. (1956) and Forattini et al. (1968) correlated the acrodendrophilic behavior of An. cruzii with its feeding preference for arboreal vertebrates resting in the forest canopy during the night. An. cruzii had been characterized as an acrodendrophilic species. Nevertheless, Veloso et al. (1956), Deane and Ferreira-Neto (1969), Deane et al. (1971) and Forattini et al. (1978) observed an homogeneous distribution of this species between the canopy and ground level, in nocturnal samples with the use of human bait. Guimarães et al. (1985) described similar behavior for diurnal samples and confirmed the preference for canopies at night. In the present study, An. cruzii showed clear preference for the nocturnal period (Fig. 1). Consequently, it would appear that the behavior of this species is strongly linked to vegetation coverage and the presence of certain hosts.

Lourenço-de-Oliveira and Heyden (1986), Guimarães et al. (1987) and Forattini et al. (1989) observed the correlation between nocturnal activity of $C x$. nigripalpus and its ornithophilic habits. They also found that in the presence of man the species showed anthropophilic behavior. Due to this capacity, these authors believe that $C x$. nigripalpus could be a possible vector of Saint Louis encephalitis virus. In the present study, this species was captured as previously recorded by Guimarães and Victório (1986) (Fig. 1).

Guimarães and Victório (1986) and Nayar (1983) reported the great potential of dispersion of $C x$. nigripalpus during the nocturnal period. In the diurnal period, this species occurred only in the dense, dark and humid forest.

Ae. scapularis had an eclectic behavior in its hematophagic activity in relation to the period of the day (Fig. 1). The same was observed by Rachou et al. (1958) in the county of Ponta Grossa, State of Santa Catarina and Guimarães and Victório (1986) in the Serra dos Órgãos National Park (PNSO). Irrespective of whether this species occurred in diurnal or nocturnal samples, it demonstrated an increase in activity during the period of sunset in these three cases. Forattini et al. (1981) in Vale do Ribeira, State of São Paulo, described the diurnal activity of Ae. scapularis with an increase in biting at sunset and the greatest incidence a little after, when already dark. Degallier et al. (1978), in Suriname, collected Ae. scapularis only in diurnal samples. Forattini et al. (1968), in Vale da Ribeira, and Lourenço-de-Oliveira and Silva (1985), in rural areas of State of Rio de Janeiro, considered this species eclectic and with a population increase just after sunset. Differences in biting peaks during the day are probably related to climatic variations such as wind, temperature, humidity and sunlight as well as under the influence of endogenous stimuli. Nevertheless it should not be forgotten that Ae. scapularis could probably be a "species complex", what could be the main source of this differences in behavior.

Ae. serratus was also an eclectic species with an increase in its activity at twilight.

Biting peaks of $C q$. chrysonotum and $C q$. venezuelensis, occurred at twilight as observed by other authors (Haddow 1954, 1960, Forattini et al. 1981, Guimarães et al. 1987) (Fig. 1).

Forattini et al. $(1981,1986)$ and Guimarães et al. (1991), found Ps. ferox to be more active during the day. The same was observed in the present study for the same species, as well as for Ps. albipes (Fig. 1). Although, in the latter species Forattini et al. (1968) found a less clearly defined biting rhythm. 
Although species of the tribe Sabethini are largely diurnal, $\mathrm{Tr}$. digitatum were collected more commonly during the crepuscular period. Davis (1945) in Fazenda Comari, Teresópolis, State of Rio de Janeiro, described the occurrence of Tr. digitatum in the darkest hours of the diurnal period on colder and drier days. The same author affirms that other species of the same genus could occur at similar times but only when the ambient humidity was high. Guimarães and Victório (1986) in PNSO, close to the area studied by Davis (1945), captured $T r$. digitatum at sunset and to a lesser degree later in the night. Forattini et al. (1968) could only sporadically collect it during the nocturnal period. Degallier et al. (1978), in Suriname, captured Trichoprosopon species, including $T r$. digitatum, exclusively in diurnal samples. Forattini et al. (1968) and Guimarães and Victório (1986) discussed the significant occurrence in nocturnal samples of $R u$. reversa and $R u$. frontosa, that were at that time identified as Trichoprosopon species. Both species presented primary diurnal activity in the present study and just rare occurrences at night (Fig. 1).

The remaining Sabethini species were captured mainly during the diurnal period. The same was observed by Davis (1945), Galindo et al. (1966), Forattini et al. (1968, 1981), Degallier et al. (1978), and Guimarães and Victório (1986).

Collections of most of the following species rapidly declined with the beginning of sunset: $W y$. dyari, Wy. mystes, Wy. aporonoma, Wy. theobaldi, Wy. flabelata, Wy. splendida, Wy. quasilongirostris, Wy. bonnei, Li. flavisetosus, Li. durhami and Li. pseudomethisticus. Other Sabethini species were captured exclusively in diurnal samples: $W y$. shannoni, Wy. palmata, Wy. longirostris and Wy. davisi, (Fig. 1). Two species behaviored as atypical Sabethini as far as biting rhythms are concerned because they were constantly present in nocturnal samples: Wy. confusa and Wy. lassalli (Fig. 1). Forattini et al. (1968, 1986) and Guimarães and Victório (1986) found the same behavior for $W y$. confusa.

Influence of the lunar cycle - It is well established that the lunar cycle affects the biting behavior of many insects. Silveira-Neto et al. (1976) considered that the phases of the moon influence the activities of insects. However, few studies can be found which analyze the influence of lunar cycle upon mosquito fauna. Bidlingmayer (1964, 1967), Degallier et al. (1978) and Charlwood et al. (1982) reported that moonlight variations could directly influence mosquito activity.

Bidlingmayer (1964) reported that hematophagic activity occurs indistinctly during the full and new moon, but that greater flight activity occurred during the more illuminated nights. In the present study, mosquito species were also active within all moon phases, but the greatest incidences occurred during the period of new moon (Fig. 2). Degallier et al. (1978) observed that nocturnal species were most influenced by moonlight variations.

Ae. scapularis were most abundant during the full moon, as had been observed by Bidlingmayer (1964). This author reported that more illuminated nights are favorable to the flight activity of some mosquitoes species. In the present study, the greatest incidence of Ae. scapularis was at a site where a scattered shrub-like vegetation coverage is found. This habitat allows a better penetration of moonlight during the full moon. However, the paucity of data precludes a correlation between this species activity and the lunar cycle. According to Bates (1949), an endogenous stimulus to hematophagic activity could in some cases influence mosquito behavior independently of environmental aspects. Lourenço-de-Oliveira and Silva (1985) suggested the existence of a "possible cycle" in mosquito activity according to the phases of the moon. This "cycle" would begin with minor activity of the mosquitoes in the last quarter moon. An increase would take place during the full moon and maximum activity would occur in the first quarter moon. During the new moon a decrease in activity was observed.

However, according to the data presented by these authors, those of Degallier et al. (1978) and the present observations, we believe that this "cycle" does not exist. Even though Williams averages for biting activities of mosquito species displayed in Fig. 2 indicate that samples collected during the new moon were more abundant, the Kruskal-Wallis test demonstrated that there is no significant influence of the lunar cycle upon the mosquitoes population. Guimarães et al. (2000 a,b) observed that non-biotic factors exert a holistic influence upon the mosquito fauna in PESM. The lunar cycle could be one of these factors, but according the Kruskal-Wallis test a direct influence of this factor upon the mosquito species could not be demonstrated.

\section{ACKNOWLEDGEMENTS}

To Dr Pedro Cabello, Research Senior from Oswaldo Cruz Institute, for the statistical support of this work.

\section{REFERENCES}

Bates M 1949. The Natural History of Mosquitoes, The Macmillan Company, New York, 379 pp.

Bidlingmayer WL 1964. The effect of moonlight on the flight activity of mosquitoes. Ecology 45: 87-94.

Bidlingmayer WL 1967. A comparison of trapping methods for adult mosquitoes: species response and environmental influence. J Med Ent 4: 200-220.

Charlwood JD, Lopes J, Whalley PC 1982. Light intensity measurement and the biting behavior of some sylvatic mosquitoes of the Amazon basin (Diptera: Culicidae). Acta Amazônica 12: 61-64. 
Davis DE 1945. The annual cycle of plants, mosquitoes birds and mammals in two Brazilian forests. Ecological Monographs 15: 243-295.

Deane LM, Ferreira-Neto JA 1969. Malária em macacos do Estado do Rio Grande do Sul. Observações preliminares. Rev Inst Med Trop São Paulo 11: 299305.

Deane LM, Deane MP, Ferreira-Neto JA, Almeida FB 1971. On the transmission of simian malaria in Brazil. Rev Inst Med Trop São Paulo 13: 311-319.

Degallier N, Pajot FX, Kramer R, Claustre I, Bellony S, Le Pont F 1978. Rythmes d'activité des Culicidés de Ia Guyane Française (Diptera, Culicidae). Cah ORSTOM, sér Ent Med Et Parasitol 16: 73-84.

Forattini OP, Gomes AC, Galati EAB, Rabelo EX, Iversson LB 1978. Estudos ecológicos sobre mosquitos Culicidae no Sistema Serra do Mar, Brasil. 1 Observações no ambiente extradomiciliar. Rev Saú Púb 12: 297-325.

Forattini OP, Gomes AC, Natal D, Santos JLF 1986. Observações sobre atividade de mosquitos Culicidae em mata primitiva da encosta no Vale da Ribeira, São Paulo, Brasil. Rev Saú Púb 20: 1-20.

Forattini OP, Gomes AC, Natal D, Kakitani I, Marucci D 1989. Preferências alimentares e domiciliação de mosquitos Culicidae no Vale da Ribeira, São Paulo, Brasil, com especial referência a Aedes scapularis e a Culex (Melanoconion). Rev Saú Púb 23: 9-19.

Forattini OP, Gomes AC, Santos JLF, Galati EAB, Rabelo EX, Natal D 1981. Observações sobre a atividade de mosquitos Culicidae, em mata residual do Vale da Ribeira, São Paulo, Brasil. Rev Saú Púb 15: 557-586.

Forattini OP, Lopes OS, Rabelo EX 1968. Investigações sobre o comportamento de formas adultas de mosquitos silvestres no Estado de São Paulo. Brasil. Rev Saú Púb 2: 111-173.

Galindo P, Srihongse S, De Rodaniche E, Grayson MA 1966. An ecological survey for arboviruses in Almirante, Panama, 1959-1962. Am J Trop Med Hyg 15: 385-400.

Guimarães AE, Victório VMN 1986. Mosquitos no Parque Nacional da Serra dos Órgãos, Estado do Rio de Janeiro, Brasil. III - Preferência horária para hematofagia. Mem Inst Oswaldo Cruz 81: 93-103.

Guimarães AE, Arlé M, Machado RNM 1985. Mosquitos no Parque Nacional da Serra dos Órgãos, Estado do Rio de Janeiro, Brasil. II - Distribuição vertical. Mem Inst Oswaldo Cruz 80: 171-185.

Guimarães AE, Arlé M, Machado RNM 1987. Mosquitos no Parque Nacional da Serra dos Órgãos, Estado do Rio de Janeiro, Brasil. IV - Preferência alimentar. Mem Inst Oswaldo Cruz 82: 277-285.

Guimarães AE, Gentile C, Lopes CM, Mello RP 2000a. Ecology of mosquitoes (Diptera-Culicidae) in areas of Serra do Mar State Park, State of São Paulo, Brazil. II - Habitat distribution. Mem Inst Oswaldo Cruz 95: 17-28.

Guimarães AE, Machado RNM, Neto B, Miranda KA 1991. Ecology of mosquitoes (Diptera-Culicidae) in the National Park of Serra da Bocaina and State Park of Serra do Mar, Rio de Janeiro and São Paulo,
Brasil. I - Seasonal variation. In II Simposio Internacional de Zoologia, Ciudad la Habana, Cuba.

Guimarães AE, Mello RP, Lopes CM, Gentile C 2000b. Ecology of mosquitoes (Diptera-Culicidae) in areas of Serra do Mar State Park, State of São Paulo, Brazil. I - Monthly frequency and climatic factors. $\mathrm{Mem}$ Inst Oswaldo Cruz 95: 1-16.

Haddow AJ 1954. Studies of the biting-habits of African mosquitoes. An appraisal of methods employed, with special to the twenty-four hours. Bull Ent Res 45: 199-242.

Haddow AJ 1960. Studies on the biting-habits and medical importance of east African mosquitoes in the genus Aedes. I - Subgenera Aedimorphus, Bankisinella and Dunnius. Bull Ent Res 50: 759779.

Harbach RE, Kitching IJ 1998. Phylogeny and classification of the Culicidae (Diptera). Sys Entomol 23: 327-370.

Judd DD 1996. Review of the systematics and phylogenetic relationships of the Sabethini (Diptera: Culicidae). Syst Entomol 21: 129-150.

Judd DD 1998. Review a bromeliad-ovipositing Lineage in Wyeomyia and the resurrection of hystatomyia. Ent Soc Am 91: 572-589.

Kruskal WH, Wallis WA 1952. Use of ranks in onecriterion analysis of variance. J Amer Statist Assoc 47: 583-621.

Lourenço-de-Oliveira R, Heyden R 1986. Alguns aspectos da ecologia dos mosquitos (Diptera: Culicidae) de uma área de planície (Granjas Calábria), em Jacarepaguá, Rio de Janeiro. IV - Preferências alimentares quanto ao hospedeiro e frequiência domiciliar. Mem Inst Oswaldo Cruz 81: 15-27.

Lourenço-de-Oliveira R, Silva TF 1985. Alguns aspectos da ecologia dos mosquitos (Diptera: Culicidae) de uma área de planície (Granjas Calábria), em Jacarepaguá, Rio de Janeiro. III - Preferência horária das fêmeas para o hematofagismo. Mem Inst Oswaldo Cruz 80: 195-202.

Machado-Allison CE 1982. Ecologia de los mosquitos (Culicidae). III - Adultos. Acta Biol Venez 11: 133 237.

Nayar JK 1983. Bionomics and Physiology of Culex nigripalpus (Diptera-Culicidae) of Florida: an Important Vector of Diseases, Florida Medical Entomology Laboratory, Institute of Food and Agricultural Sciences, University of Florida, Vero Beach, $186 \mathrm{pp}$.

Rachou RG, Moura-Lima M, Ferreira-Neto JA, Martins CM 1958. Alguns dados sobre o comportamento de mosquitos de Ponta Grossa (Florianópolis, Santa Catarina). Rev Brasil Malariol D Trop 10: 417-427.

Silveira-Neto S, Nakano O, Barbin D, Villa-Nova NA 1976. Manual de Ecologia dos Insetos, Ed. Agronômica Ceres, São Paulo, 419 pp.

Veloso HP, Fontana-Junior P, Klein RM, SiqueiraJaccoud RJ 1956. Os anofelinos do subgênero Kerteszia em relação à distribuição das bromeliáceas em comunidades florestais do município de Brusque, Estado de Santa Catarina. Mem Inst Oswaldo Cruz 54: 1-86. 